\title{
„Jesteśmy zdolni do prawdziwego spotkania z Drugim”. Z Marci Shore rozmawia Magdalena Brodacka-Dwojak
}

\author{
"We Are Capable of a Real Encounter with the Other." Marci Shore \\ in Conversation with Magdalena Brodacka-Dwojak
}

Magdalena Brodacka-Dwojak (M.B.D.): Chciałabym naszą rozmowę rozpocząć od nadziei. Wydaje się, że wkroczyliśmy w okres zdominowany wieloma kryzysami - i w tej konstatacji nie byłoby nic nadzwyczajnego, gdyby nie fakt, że z dnia na dzień w wielu z nas potęguje się uczucie niepewności, które skutkuje permanentnym niepokojem i funkcjonowaniem we wzmożonym stresie. Niepewność dotyczy zmian, które już do nas dotarły i które prawdopodobnie przekroczyły nasze zdolności wyobrażeniowe, a co za tym idzie - językowe, dyskursywne.

W moim odczuciu w tę wyrwę wywołaną niemożnością wyobrażenia sobie świata lepszego, zdrowszego, czy po prostu innego, powinna wejść nadzieja. Czesław Miłosz pisał, że człowiek, który nie ma w sobie nadziei, myśli, że świat, który go otacza, jest złudzeniem; że jeśli odwróci wzrok, to wszystko wokół zniknie. Nadzieja miałaby więc być odpowiedzią na pustkę i zwątpienie. Czym nadzieja jest Twoim zdaniem? Kto Ciebie jej uczył i od kogo dziś możemy ją czerpać?

Marci Shore (M.Sh.): Nadzieja jest czymś, co przekracza rozum. Myślę o tym, co pisze Leszek Kołakowski o utopii w eseju Sens ideowy pojęcia lewicy: „utopia jest dążeniem do przemian (...), które leżą poza przyszłością widzialną i dającą się planować”. Myślę też o Hannah Arendt i jej pojęciu „natalności”, czyli ludzkiej zdolności rozpoczynania czegoś nowego...

Nadzieja to niby wiara, chociaż bez pewności. Nie jestem osobą wierzącą, mam tu na myśli wiarę w Boga, jestem raczej agnostyczką Żydówką. Ale mam dzieci i właśnie dlatego, że sprowadziłam te dzieci na świat, muszę mieć nadzieję, że możemy ten nasz smutny świat uczynić lepszym. Siedem lat temu Majdan

1 L. Kołakowski, Sens ideowy pojęcia lewicy [w:] tegoż, Pochwata niekonsekwencji, t. 2, Warszawa 1989, s. 17. 
w Ukrainie tak szalenie mnie zachwycił i urzekł właśnie z tego powodu, że był to ten akt wiary, moment przekroczenia siebie samego, ten Augenblick - mgnienie oka - który nas oświetla i pokazuje, że pomimo wszelkiego zła, pomimo wszystkich naszych klęsk, jesteśmy, jako ludzie, zdolni do czegoś lepszego, że posiadamy w sobie tę możliwość, nawet jeżeli ujawnia się ona bardzo rzadko.

M.B.D.: W swoich książkach opowiadasz nam - Polakom, ale również Czechom, Ukraińcom i w ogóle Środkowoeuropejczykom - naszą historię. Wydobywasz ją z archiwów, tworzysz z tego, co dzieje się na ulicach Ukrainy pogrążonych w rewolucji. Ale w twojej twórczości jest „coś więcej” niż prawda historii - ukazuje się w nich drugi człowiek. Nie boisz się go spotkać, nawet jeśli to postać nieoczywista, pełna sprzeczności, jak chociażby działacze komunistyczni, czy przekraczający kolejne granice awangardowi twórcy. I zawsze, gdy myślę o twojej twórczości, to widzę i słyszę twoich bohaterów i twoją rozmowę z nimi. Opowiedz coś więcej o swojej metodzie pracy, języku oraz formie, za pomocą której „czytasz” historię i rzeczywistość wokół ciebie.

M.Sh.: Bardzo dobrze pojmujesz, o co chodzi w moich książkach: czyli o rozumienie drugiego człowieka, o wykonanie skoku wyobraźni do miejsca i do czasu nieswojego. Zdaję sobie sprawę z tego, że takie rozumienie nigdy nie może być pełne, zawsze będzie częściowe, że nie sposób obejrzeć nagiej duszy drugiego człowieka. (Jak wiemy od Sigmunda Freuda, nawet swojej jaźni nie potrafimy w pełni obejrzeć, jaźń jest zawsze ukryta nie tylko przed drugimi, ale także przed soba). Zawsze są granice epistemologiczne. A jednak trzeba się starać. Dla mnie to jest proces wczytania, przede wszystkim przez intensywne czytanie. Staram się skupić nie tylko na wydarzeniach, ale także na głosach, tonie, nastroju, estetyce, spotkaniach, związkach, uczuciach. To jest próba przenikania, proces bardzo inwazyjny. W pewnym sensie doświadczenie empatii wymaga voyeuryzmu. Jednocześnie staram się wziąć w nawias - żeby skorzystać z myśli Edmunda Husserla - wiedzę o tym, co stało się potem. Szalenie trudno jest pisać na przykład o Warszawie w 1926 roku bez myślenia o tym, że za parę lat dojdzie do władzy Józef Stalin, za kilka kolejnych Adolf Hitler, że będą czystki, że przyjdzie wojna. Jednak żeby rozumieć wybory tych, którzy działali w 1926 roku, trzeba pamiętać, że oni nie wiedzieli, co nadejdzie. To, co nadeszło, przekroczyło to, co dało się wyobrazić w 1926 roku. My, historycy, zawsze musimy zmagać się z teleologicznymi złudzeniami retrospekcji. Niby wszystko to wydawało się niemożliwe, aż do momentu, kiedy stawało się nieuniknione.

Poza tym z reguły nie piszę o tych, których nie udaje mi się wcale zrozumieć. Staram się pisać tylko wtedy, kiedy odczuwam, że osiagnę̧łam pewien stopień rozumienia. Mój brat, Dan Shore, jest kompozytorem. Pisze opery. Rok temu (tuż przed przybyciem dżumy) miała miejsce premiera jego opery Freedom Ride w Chicago. To historia, która rozgrywa się w 1961 roku w Nowym Orleanie podczas ruchu na rzecz praw obywatelskich. To jest historia 
egzystencjalna: bohaterka, młoda czarna kobieta, musi podjąć decyzję, czy wsiąść do autobusu, ryzykując swoje życie. To nie jest łatwa ani oczywista decyzja. Kobieta mierzy się z głosami sprzeciwu: swojej mamy, innych kolegów i znajomych, też czarnych, którzy będą ponosili skutki decyzji i czynów aktywistów działających w ich sprawie (Dara Rahming, śpiewaczka, która odegrała rolę Sylvie Davenport, jest nadzwyczajna, ma głos nie z tego świata: https:// www.danshoremusic.com/freedomride).

Mój brat udzielał różnych wywiadów prasie i pamiętam, że pewien dziennikarz zadał mu pytanie: dlaczego nie ma w tej operze żadnych kluczowych postaci z Ku Klux Klanu? Dan odpowiedział, że aby wprowadzić postać na scenę, musi mieć poczucie, że rozumie tę postać, że jest ona trójmiarowa, że jest całym, pełnym człowiekiem, nawet jeżeli on osobiście się z nią nie zgadza, nie lubi jej itp. I w końcu nie potrafił stworzyć kogoś z Ku Klux Klanu. Dla mojego brata to była granica, której nie mógł przekroczyć. Nie był w stanie w wystarczającym stopniu zrozumieć człowieka, który bił czy mordował innego tylko dlatego, że ten odważył się usiąść w części autobusu przeznaczonej dla białych. Więc w tej operze klansmeni pojawili się wyłącznie za kulisami.

Rozumiałam jego decyzję - najciekawsze jest to, że mimo iż ja jestem historyczką, a on kompozytorem, w naszej twórczości zmagamy się z tymi samymi pytaniami i dylematami.

M.B.D.: Które ze „spotkań”, czy to osobistych, czy na kartach książek, korespondencji i w czeluściach archiwów, były dla ciebie szczególnie ważne, poruszające? Jest to również pytanie o obcowanie z tymi postaciami przez długi czas pracy nad publikacją. Jak ci się „żyje” z twoimi bohaterami, jakie masz z nimi relacje, czy i jak wpływają na twój ogląd rzeczywistości?

M.Sh.: Tak, „obcowanie” (należące do ulubionych słów Krzysztofa Czyżewskiego) jest właściwym słowem.

Wiesz, przeżywałam rozmaite okresy podczas lat pracy nad książką $\mathrm{Ka}-$ wior i popiót. Życie i śmierć pokolenia oczarowanych $i$ rozczarowanych marksizmem. Bardzo przeżywałam również - zanim nawet wiedziałam, o czym napiszę - Mój wiek Aleksandra Wata. Wina, wybory, które nie dają się cofnąć. Natomiast znacznie wolniej zbliżałam się na przykład do Władysława Broniewskiego. Mój stosunek do niego ciągle się zmieniał. Kiedy czytałam jego korespondencję z Janiną Kunig (później Broniewską), wtedy jego narzeczoną, i zorientowałam się, że w tym samym czasie w Krakowie mieszkała kobieta, która była z nim w ciąży, o której Broniewski pisał, jakby to ona go zgwałciła (co wydawało mi się mało prawdopodobne), a on był zupełnie niewinny, byłam oburzona - nie tylko dlatego, że zdradzał swoją narzeczoną, a bardziej z tego powodu, że nie poczuwał się do odpowiedzialności. Pisał o tej kobiecie z Krakowa w taki chłodny, surowy sposób, zmuszał ją do usunięcia ciąży. Jakiś rok później siedziałam w mieszkaniu w Kalifornii z kolegą, który pomagał mi 
odszyfrować rosyjski rękopis protokołu przesłuchań Broniewskiego w radzieckim więzieniu. I wtedy, jak czytaliśmy z Saszą te protokoły na głos, byłam pod ogromnym wrażeniem niesłychanej odwagi i pryncypialności Broniewskiego. W najstraszniejszych, najbardziej zagrażających warunkach jego mózg nadal genialnie działał, nie złamał się, starał się ochronić swoich kolegów, zachowywał się z niesamowitą godnością.

Przyjaźń między Wandą Wasilewską a Janiną Broniewską szczególnie mnie wzruszyła. Prześladowało mnie pytanie, co Wanda Wasilewska wiedziała o zamordowaniu swojego drugiego męża, Mariana Bogatki, we Lwowie, jak potrafiła się z tym pogodzić i czy naprawdę zdołała się z tym pogodzić. Lata temu, będąc w Moskwie, odwiedziłam Ewę Wasilewską, córkę Wandy Wasilewskiej. Odważyłam się zapytać ją o tę śmierć. Pani Ewa - ogromnie sympatyczna, inteligentna, obdarzona samorefleksją kobieta - odpowiedziała mi, że do końca życia jej mama nie powiedziała na ten temat ani jednego słowa (co było dla pani Ewy bardzo bolesne, ponieważ kochała Bogatkę, który ją wychował i którego uważała za swojego ojca). Domyślam się, że jedyną osobą, która zdawała sobie sprawę z tego, co Wanda Wasilewska wiedziała i jaki miała stosunek do tego morderstwa, była Janina Broniewska. A ona zabrała tę tajemnicę ze sobą do grobu.

M.B.D.: To dobry moment, żeby zapytać cię, nad czym teraz pracujesz, albo raczej - z kim teraz na łamach swojej książki rozmawiasz. I dlaczego to właśnie takich, a nie innych bohaterów wybrałaś.

M.Sh.: Pracuję teraz nad książką, o której myślę już od prawie ćwierć wieku. Książka w pewnym sensie opowiada historię fenomenologii, czyli ruchu fenomenologicznego w Europie Środkowo-Wschodniej. Trwało lata, aż przekonałam się, że jestem zdolna do jej napisania (i nawet dzisiaj czasami mam wątpliwości...).

Kluczową rolę odegrało spotkanie z Krzysztofem Michalskim w 2004 roku w Wiedniu. Wtedy Tony Judt wysłał mnie do Instytutu Nauk o Człowieku, abym pracowała z Michalskim. W lutym 2005 roku Krzysztof zaprosił mnie wraz z mężem na kolację do swego wspaniałego wiedeńskiego mieszkania z drewnianymi podłogami i wysokim stropem. Polska kucharka w instytucie przygotowała śledzia w oleju i pierogi, w mieszkaniu Krzysztofa podawała je ubrana na czarno Austriaczka, wydawała się jakby zbyteczna. Krzysztof mówił z nami po polsku, a zwracając się do swej austriackiej gosposi, dalej używał tego języka; ona patrzyła na niego, nic nie rozumiejąc, zanim wreszcie przeszedł na niemiecki. A potem mówił po niemiecku do nas, aż po kolejnych kilku minutach, jakby wybudzając się ze snu, przypomniał sobie, że to przecież nie w tym języku ze sobą rozmawiamy. Po kolacji gosposia wyszła, a my we troje dalej siedzieliśmy w salonie, pijąc wódkę, podczas gdy Krzysztof mówił do nas, chodząc i przesuwając w palcach różaniec albo może korale. W pewnym 
momencie, chyba już po północy, owijając sobie różaniec wokół ręki, podarował mi egzemplarz swojej pierwszej książki o filozofii Martina Heideggera.

To był przełomowy moment: chyba od razu następnego dnia (nie mieliśmy jeszcze wtedy dzieci) zaczęłam tę książkę czytać. I jakoś wszystko, co wcześniej było dla mnie niby niedostępne i nie do przejścia, zaczęło mieć sens. W końcu bardziej zmagałam się z Edmundem Husserlem niż z Martinem Heideggerem. Czytaliśmy razem z Krzysztofem Logische Untersuchungen. Kiedyś, podczas spotkania w Bostonie, zadałam mu jakieś kolejne pytanie o Husserla. A Krzysztof mi wtedy odpowiedział: „Marci, on nie był do ciebie podobny - nie miał żadnego życia emocjonalnego".

Od tego wieczora w Wiedniu minęło jeszcze kilka lat, zanim znalazłam właściwą formę dla książki, w dużej mierze dzięki esejowi Józefa Tischnera Spotkanie i powieści Ludmiły Ulickiej, Zielony namiot [Желеный Шатер]. Tischner dał mi kluczowy wątek, mianowicie „spotkanie”: „Spotkanie jest czymś więcej niż zwyczajnym "zetknięciem się" z drugim, widzeniem czy słyszeniem drugiego. Spotkanie to Wydarzenie. Od spotkania zaczyna się dramat, którego przebiegu nie da się przewidzieć"2. Ulicka dała mi strukturę nowoczesnej powieści epickiej. Tytuł, na razie prowizoryczny - Eyeglasses Floating in Space: Central European Encounters That Came about While Searching for Truth - zaczerpnętam z listu Witkacego do Romana Ingardena: „Husserl to dla mnie: oczy, okulary i broda bez ciała" ${ }^{3}$.

Autorem najbardziej mi pomocnym w rozumieniu Husserla jest Lew Szestow, który z czasem sam stał się jednym z głównych bohaterów tej jeszcze niedopisanej książki. Już czuję, że jest mi bliski. Tu też jest element przypadku: w grudniu 2014 roku byłam w Kijowie w związku z pracą nad swoją książką o Majdanie. Spotkałam się tam, dzięki Oli Hnatiuk, z Leonidem i Leną Finbergami, parą, która będąc już niemłodymi ludźmi i dziadkami, brała aktywnie udział w rewolucji. Toczyła się już absurdalna wojna w Donbasie, dlatego ludzie masowo uciekali do innych części Ukrainy. Leonid i Lena zawieźli mnie samochodem do nowego centrum dla uchodźców, zorganizowanego przez ich syna. Po drodze mijaliśmy pewien budynek i Leonid zwrócił uwagę, że kiedyś mieszkał tam Lew Szestow. Trochę Szestowa już wcześniej czytałam, ale z jakiegoś powodu to przypadkowe zetknięcie z nim zainspirowało mnie, by wrócić do niego. I chyba to był po prostu właściwy moment w moim życiu, by związać się z Szestowem.

Momentami piszę też o Tadeuszu Krońskim i Irenie Krońskiej, to fascynujące postacie. (To Irena Krońska przedstawiła młodego Krzysztofa Michalskiego Janowi Patočce w Pradze. Było to po marcu 1968, kiedy Leszek Kołakowski

2 J. Tischner, Spotkanie [w:] tegoż, O cztowieku. Wybór pism filozoficznych, red. A. Bobko, Wrocław-Warszawa-Kraków 2003, s. 242-243.

3 R. Ingarden, S.I. Witkiewicz, Korespondencja filozoficzna, red. B. Michalski, Warszawa 2002, s. 32. 
i inni profesorowie wyemigrowali, Wydział Filozoficzny zniszczono, a w Warszawie nie było u kogo napisać rozprawy doktorskiej o Heideggerze...).

M.B.D.: Na koniec chciałam powrócić do nadziei, która w moich pytaniach cały czas oscylowała wokół spotkania z drugim człowiekiem, tym słynnym Innym. Może jest tak, że nasza niepewność, kryzys, wszechobecne wyczerpanie przeróżnych narracji, o których piszą badacze, są tak naprawdę wyrazem pewnego osamotnienia w wielości i natłoku. I nie mówię tu tylko o rzeczach przykrych, ale o nadmiarze w ogóle. Może w tej rzeczywistości nie potrafimy już być ze sobą solidarni - jako partnerzy, społeczeństwo, wspólnoty. Miłosz w Nadziei pisał: „Gdybyśmy lepiej i mądrzej patrzyli...”. No właśnie - na czym to lepiej i mądrzej mogłoby polegać? I nie pytam o diagnozę i receptę, pytam o drogi, którymi moglibyśmy pójść, żeby tej nadziei nie stracić.

M.Sh.: To jest właściwe pytanie. Chyba tylko wtedy, kiedy znajduję się w Krasnogrudzie, zaczynam wierzyć, że może jednak ten nasz smutny świat da się uratować. Jak wiesz, to wyjątkowe miejsce. To jest miejsce sztuki, teatru, filozofii, literatury, muzyki, a jednocześnie pracy u podstaw. Krzysztof Czyżewski jest mistrzem sztuki rozmowy. To umierająca sztuka, której nie można lekceważyć. (W lipcu 2016 zatrzymaliśmy się z rodziną na kilku dni w Warszawie w drodze z Wiednia do Krasnogrudy. Akurat wtedy oglądałam w hotelu w Warszawie telewizyjną relację z Narodowej Konwencji Republikanów, kiedy formalnie nominowano Donalda Trumpa na kandydata na prezydenta. Jednocześnie dotarła do nas wiadomość o zamordowaniu w Kijowie dziennikarza Pawla Szeremeta, który dwa tygodnie wcześniej przeprowadził wywiad z moim mężem we Lwowie. Kiedy koledzy pytali, „gdzie jedziecie na wakacje?”, zaczęłam odpowiadać: „Jedziemy na obóz antyfaszystowski, pod prąd" - mając na myśli oczywiście Pogranicze, niby żartując, ale nie do końca...).

Żyjemy na tym świecie - jak pisze Heidegger - „już zawsze” razem. Więc jeżeli chodzi o drogi, wspomnę o tym, co już jest pewnie dla Ciebie oczywiste: Zawsze trzeba pamiętać, że mamy do czynienia z ludźmi. Jak nam mówi Immanuel Kant: „Trzeba traktować każdego człowieka jak cel sam w sobie, a nie jak środek do celu".

Potrzebujemy mniej rywalizacji, a więcej wielkoduszności. Precz z tą polityką historyczną. Precz z tą obsesją na temat „wielkości”: nie ma ani doskonałego narodu, ani doskonałego kraju, ani doskonałego ludu. Przestańmy się kłócić o to, kto kogo powinien przeprosić za przeszłość. Starajmy się razem rozumieć tę przeszłość - nie usprawiedliwiać się, nie mścić, ale raczej rozumieć. To rozumienie nigdy nie będzie doskonałe, ale tym bardziej musimy się bezustannie starać. Słuchajmy, wyciągajmy rękę do drugiego, starajmy się wykonać skok wyobraźni do miejsca, w którym jest Inny, właśnie przez budowanie tego „niewidzialnego mostu”, o którym się mówi w Pograniczu. 
Może wiesz, że w tym roku umarł słynny działacz na rzecz praw obywatelskich, długoletni poseł, Afroamerykanin John Lewis. Na pogrzebie ksiądz James Lawson czytał wiersz Miłosza, którego imię i nazwisko ojciec Lawson niezrozumiale wymówił. Dla mnie to był szczególnie poruszający moment: bo przecież ta zła wymowa była znakiem, że ojciec Lawson, ksiądz i przyjaciel Umarłego, odnosi się do części świata, której sam dobrze nie zna, ale w której znalazł coś, co rezonuje w nim, mówi do niego, coś znaczącego dla niego. To przypomnienie dla nas wszystkich, po co jest poezja, po co jest literatura, że ona może być tym niewidzialnym mostem, że jesteśmy zdolni do zrozumienia, do prawdziwego spotkania z Drugim. 